hibition. Allowing a defendant to claim collateral estoppel in a criminal case enables him to overcome these limitations on double jeopardy protection. The law therefore comes closer to achieving its policy objectives. It is reasonable, then, to suggest that collateral estoppel be viewed in criminal cases as a rule designed to further the policy of the double jeopardy prohibition through the avoidance of limitations imposed upon the prohibition by judicial desire for the simplicity of the "same offense" doctrine.

Under the suggested rationale, there is no reason for permitting the prosecution to use collateral estoppel. Permitting such use would not prevent successive trials. It might even encourage them by decreasing the number of facts that the prosecution would have to prove in a second trial. Denying collateral estoppel to the prosecution while allowing it to the defendant would, however, tend to discourage successive trials. The prosecutor, knowing that he would have no special advantage in a second trial if he obtained a conviction in the first, would be facing a defendant who would have a decisive advantage in the second trial if the first ended in acquittal. Under such circumstances, the prosecutor probably would consider it wise to join all charges in one trial and to work hard on convicting in that trial.

But even if the rule of mutuality withstands the arguments against prosecution use of collateral estoppel, then, precisely because of the mutuality rule, the prosecution should not be allowed to use collateral estoppel in courts which hold that general acquittal verdicts decide no specific issues. For in such courts the defendant cannot use collateral estoppel, and the rule of mutuality should be brought into play against the prosecution's use of the doctrine. 38

38 See note 8 supra.

\title{
VOTING RIGHTS IN THE STOCK OF A PARENT CORPORATION HELD BY A SUBSIDIARY
}

Proper allocation of voting rights in the stock of a parent corporation held by a subsidiary has long posed a seemingly insoluble problem for courts and commentators alike.1 Ordinarily such stock has been disfranchised on the

\footnotetext{
1 Ballantine, Corporations $\$ 176$ (rev. ed. 1946), states the general rule: "The corporation cannot vote shares of its own issue acquired by it, nor can a wholly owned or dominated subsidiary or affiliate vote shares in its parent or controlling corporation, as the management of the parent could control the vote on its own behalf." Id. at 402.

In accord with Ballantine are Levy, Purchase by a Corporation of Its Own Stock, 15 MrNN. L. REV. 1, 6 n.28 (1930); FletCHER, CyClOPEDIA CoRPORATIONS $\$ 2040$ (1952); Ex parte Holmes, 5 Cowen (N.Y.) 426 (1826); American Railway-Frog Co. v. Haven, 101 Mass. 398 (1869); O'Connor v. International Silver Co., 68 N.J. Eq. 67, 59 Atl. 321 (1904), aff'd, 68 N.J. Eq. 680, 62 Atl. 408 (1905); Thomas v. International Silver Co., 72 N.J. Eq. 224, 73 Atl. 833 (1907); Italo Petroleum Corp. v. Producers' Oil Corp., 20 Del. Ch. 184, 174 Atl. 276
} 
ground that the directors of the parent corporation could control the vote on their own behalf and perpetuate their managerial control contrary to the preference of a majority of the stockholders. However, this solution deprives the subsidiary's minority shareholders of any voice in the direction of the parent even though they are the ultimate beneficial owners of equity capital investment in that corporation.

In the recent decision in United States v. E. I. du Pont de Nemours \& Co., 2 the district court ordered that voting rights in General Motors stock held by duPont be distributed to the du Pont shareholders. ${ }^{3}$ This unique "pass through" remedy may be useful in determining the proper allocation of voting rights in a subsidiary's shares of its parent corporation. The basic corporate theory which supports a solution of the parent-subsidiary problem may also find application in solving the related problem of the allocation of voting rights in shares of an employer corporation held by an employee profit-sharing or pension fund when the trustees of the fund are appointed by the directors of the employer corporation. 4

Heretofore, those who have considered the problem of voting rights in a subsidiary's shares of its parent have confined their approach to a determination of whether such stock is or is not sufficiently similar to treasury stock to require its disfranchisement. ${ }^{5}$ Moreover, they have assumed that the only factor which compels disfranchisement of treasury shares is the possibility of directors using such voting power to perpetuate their managerial control contrary to the best interest of the stockholders. It is submitted that this is a reason for denying voting rights in treasury shares to directors ${ }^{6}$ but not a sufficient

(1934); Continental-Midwest Corp. v. Hotel Sherman, Inc., 13 Ill. App. 2d 188, 141 N.E.2d 400 (1957).

In disagreement with the rule stated by Ballantine are WORMSER, THE DISREGARD OF THE CORPORATE Fiction AND Allied CORPORATE PROBLEMS 89 (1929); Vanderlip v. Los Molinos Land Co., 56 Cal. App. 2d 747, 133 P.2d 467 (1943). See also Annot., 90 A.L.R. 315 (1934).

2177 F. Supp. 1 (N.D. Ill. 1959).

3 The acquisition of approximately $63,000,000$ shares of General Motors Corp. common stock by E. I. du Pont de Nemours \& Co. had been held by the United States Supreme Court to be a violation of section 7 of the Clayton Act. 353 U.S. 586 (1957). Upon remand for a determination of the relief to be granted, the district court ordered: " 1 . Du Pont will be divested of the right to vote any of the $63,000,000$ shares of General Motors stock which it owns and such shares will be voted hereafter by the stockholders of du Pont. ..." 177 F. Supp. at 52 .

4 For example, in 1958, the Savings and Profit Sharing Pension Fund of Sears, Roebuck \& Co. held approximately $26 \%$ of the common stock of the company. Four of the six trustees who voted shares held by the fund were also directors of the company, according to the notice for annual meeting of shareholders dated April 5, 1958.

5 In each of the cases cited supra in note 1 the court held that either all or none of parent corporation's stock held by the subsidiary or trust could be voted by the directors of the subsidiary. No other solution was discussed.

${ }^{6}$ The mere possibility of self-interest is not a sufficient reason to deny all voting rights to directors. It is well settled that the voting rights of a shareholder or director in his own stock 
reason for complete disfranchisement. To support the denial of all voting rights in treasury shares, the possibility of abuse of such voting rights by directors must be coupled with the fact that distribution of these voting rights to the beneficial owners, the stockholders, would be futile because the proportional voting power of each stockholder would remain unchanged. There is also an additional and more direct reason for the disfranchisement of such shares. Treasury shares and shares of a parent held by a wholly owned subsidiary do not represent any investment in the enterprise. 7 Hence, the very purpose of corporate voting - to enable the shareholder to foster and protect his investment ${ }^{8}$-is absent. Shares of a parent corporation held by a subsidiary, on the other hand, do represent investment in the parent enterprise in proportion to the interest in the subsidiary not held by the parent and, unless they are nonvoting shares, should be accorded voting representation.

The control of the parent's directors over the subsidiary's directors, and the consequent danger of abuse, certainly is a sufficient reason to deny the exercise of this voting power to the directors; but it does not justify total denial of voting representation. Would it not be more reasonable to allow the minority shareholders of the subsidiary to protect their own interest by exercising the voting rights attributable to their investment? 9 The same considerations are present in the case of employee profit-sharing and pension funds which hold shares of the employer corporation. Where the directors appoint the trustees of the fund and the self-perpetuation danger disqualifies the trustees from voting, the employees should be empowered to protect their own investment.10

are not affected by the existence of an interest adverse to some other shareholders. However, the possibility of self-interest is sufficient to disqualify a director from exercising voting rights allocable to the investment of other shareholders to whom his personal interest may be adverse.

7 Although legal authorities have not generally considered the fact that treasury shares and shares of a parent held by a wholly owned subsidiary do not represent a beneficial capital interest in the issuing and parent corporations respectively, this point has been made with force by the accounting profession. See, e.g., SunLEY \& CARTER, CORPORATION ACCOUNIING 367 (rev. ed. 1944); Paton, AdVANCEd AcCounting 783 (1941); MONIgOMERY, Audiring THEORY AND PRACTICE 518 (6th ed. 1940). Thus, in order to obtain a true picture of the capital structure of an enterprise in terms of real assets, accountants eliminate intercorporate holdings in the preparation of consolidated balance sheets.

8 "The right to vote for directors, therefore, is the right to protect property from loss and make it effective in earning dividends. . . . Unless the . . . stockholder can protect his investment in this way he cannot protect it at all, and his property might be wasted by feeble administration and he could not prevent it." Vann, J. in Lord v. Equitable Life Assur. Soc'y, 194 N.Y. 212, 228-29, 87 N.E. 443, 448-49 (1909).

${ }^{9}$ That portion of the stock of a parent held by a subsidiary which is allocable to the parent should be disfranchised upon either rationale supporting the disfranchisement of treasury shares: It does not represent any investment in the parent, and, further, distribution to the shareholders of the parent would not produce a result different than disfranchisement.

10 Sears, Roebuck \& Co. adopted such a "pass through" device in 1958 in order to give a voice in management to its employees, who were the beneficial owners of $26 \%$ of the com- 
The only objection to such a procedure might be its cost. Distribution of voting rights in the parent's stock to minority shareholders of the subsidiary in proportion to their interest in that corporation would involve substantially the same administrative costs as would the holding of a normal election by the subsidiary with the parent excluded. While expense may be good reason to refrain from routine use of the "pass through" technique, it should not deter its employment when control of the parent corporation might thereby be altered.

mon stock of the company held by their savings and profit-sharing pension fund. Shares held by the fund were assigned to individual employee accounts in accordance with the interest of each employee in the fund. The employees are now furnished with proxy statements prior to elections. They submit their votes to an accounting firm which tabulates the results and furnishes voting instructions to the trustees. In this manner, voting rights are accorded to the beneficial owners of this large block of stock and the secrecy of the choice of individual employees is maintained. See also note 4 supra.

\section{RETROACTIVE DETERMINATION UNDER 18 U.S.C. § 4245 OF A PRISONER'S INCOMPETENCY TO STAND TRIAL}

In 1949, Congress added four new sections to chapter 313 of title 18, U.S.C., which deals with mentally defective persons accused or convicted of federal crimes. ${ }^{1}$ In adding section 4245 , Congress provided a procedure for vacating a sentence on the ground of mental incompetency at the time of the trial. The section requires that the district court in which the prisoner was convicted hold a hearing:

Whenever the Director of the Bureau of Prisons shall certify that ... [the prisoner] has been examined by the board of examiners referred to in . . . section 4241 and that there is probable cause to believe that ... [he] was mentally incompetent at the time of his trial, provided the issue of mental competency was not raised and determined before or during said trial....2

1 Chapter 313 presently includes sections $4241-48$. Sections $4241-43$ were enacted into positive law by the Act of June $25,1948,62$ Stat. 855 , which included all of Title 18 . All three were re-enactments, with minor changes, of the provisions of a 1930 act, 46 Stat. 272. Sections $4244-48$ were added in 1949, 63 Stat. 686 (1949). The House report explains the addition of these sections:

"Existing Federal statutes prescribe no procedure whatever for determination of an accused person's mental competence to stand trial and there are but few judicial decisions on the question. Consequently, the courts have dealt with suspected cases in various ways as their judgment of the particular case dictated. The importance of uniform treatment is thus made apparent. ... The bill is the result of prolonged, patient, and painstaking study and reflection by a constituted committee of judges ... and representatives of the Attorney General. Its early enactment would be of substantial assistance in clarifying a constantly recurring and vexatious problem." H. R. REP. No. 1309, 81st Cong., 1st Sess. 1-2 (1949).

$2 \S 4245$. Mental incompetency undisclosed at trial.

"Whenever the Director of the Bureau of Prisons shall certify that a person convicted of an offense against the United States has been examined by the board of examiners referred 